\title{
POLSKIE ANALIZY STRATEGICZNE - PRZEGLĄD 2015 ROKU
}

W ubiegłorocznym numerze „Przeglądu Strategicznego” zapoczątkowano cykl publikacji stanowiących przegląd polskich analiz strategicznych. Niniejszy artykuł stanowi jego kolejną odsłonę i zawiera (siłą rzeczy subiektywny) przegląd wybranych artykułów opublikowanych w 2015 r. na łamach czołowych polskich czasopism podejmujących problematykę bezpieczeństwa międzynarodowego („Bellona”, „Bezpieczeństwo Narodowe”, "Rocznik Strategiczny” oraz „Stosunki Międzynarodowe”). Zamysłem przyświecającym autorowi było uchwycenie głównych kierunków badań nad bezpieczeństwem międzynarodowym prowadzonych $\mathrm{w}$ polskich ośrodkach w omawianym czasie oraz zaprezentowanie głównych stanowisk w prowokowanej przez nie dyskusji.

Rok 2015 przyniósł postępującą destabilizację międzynarodowego środowiska bezpieczeństwa, zarówno w wymiarze globalnym, jak i w kluczowych regionalnych kompleksach bezpieczeństwa. Chociaż aktywna konfrontacja zbrojna we wschodniej Ukrainie pozostawała (przez większą część roku) ,zamrożona” to rosnący antagonizm na linii Rosja-Zachód jedynie przybrał na sile i zaczął ogarniać coraz to nowe obszary. Niewatpliwie najbardziej spektakularnym wydarzeniem 2015 roku, z perspektywy bezpieczeństwa międzynarodowego, było bezpośrednie zbrojne zaangażowanie Federacji Rosyjskiej w konflikt syryjski. Przy tej okazji ustanowiono co najmniej kilka precedensów. Nie dość, iż jest to pierwsza od czasu rozpadu ZSRR rosyjska interwencja zbrojna poza obszarem poradzieckim, to jeszcze w wyniku eskalacji napięcia i prowokacji na pograniczu syryjsko-tureckim doszło do pierwszego od 63 lat przypadku zestrzelenia rosyjskiego/radzieckiego samolotu przez państwo NATO (Gibbons-Neff, 2015). Chociaż bezpośrednich i dalekosiężnych konsekwencji tego incydentu nie należy przeceniać, to jednak nie sposób nie zauważyć, iź świadczy on o gwałtownie rosnącej skłonności niektórych kluczowych aktorów międzynarodowych do stosowania argumentu siły. Rosyjska interwencja ostatecznie dopełniła dzieła przekształcenia syryjskiej wojny domowej w ,geopolityczną szachownicę”, na której okazji do zadania mata (a przynajmniej utrącenia kilku figur) szukają już niemal wszyscy kluczowi gracze globalni i regionalni.

Konflikt ten stanowi jedno z najważniejszych, ale nie jedyne ognisko destabilizacji w regionie Bliskiego Wschodu i Afryki Północnej. Można w tym kontekście wspomnieć chociażby o postępującej dekompozycji politycznej Libii czy eskalacji wojny domowej w Jemenie. Porozumienie w sprawie irańskiego programu nuklearnego zawarte w lipcu stanowi jedną z niewielu szans na załagodzenie regionalnych antagonizmów, chociaż kwestia jego ostatecznych rezultatów pozostaje wciąż otwarta. Po- 
stępująca polityczna dezintegracja Bliskiego Wschodu (którą François Heisbourg porównuje do wojny trzydziestoletniej, Heisbourg, 2015: 9). stwarza zasadnicze wyzwania i zagrożenia dla bezpieczeństwa Unii Europejskiej w postaci powiązanych ze sobą (choć nie tożsamych) problemów tzw. Państwa Islamskiego oraz masowej migracji. Z kolei w regionie Azji i Pacyfiku polityka Chińskiej Republiki Ludowej charakteryzuje się rosnącą asertywnością odnośnie sporu terytorialnego o wyspy na Morzu Południowochińskim. Sztuczne powiększanie kontrolowanych przez to państwo skał, raf i wysepek budzi rosnący sprzeciw państw regionu. Stany Zjednoczone odbierają to również jako wyzwanie dla ich dominującej pozycji w regionie i odpowiadają chociażby „patrolami wolności żeglugi” na spornych wodach. Wszystkie te wydarzenia i procesy składają się na to co Chester A. Crocker określa mianem „dryfującego świata" w odniesieniu do „bezładnej mieszanki turbulencji i dryfu w relacjach między czołowymi potęgami i kluczowymi państwami regionalnymi" (Crocker, 2015: 7).

Zarysowane powyżej trendy w rozwoju międzynarodowego środowiska bezpieczeństwa znalazły naturalnie odzwierciedlenie w tematyce poruszanej na łamach omawianych czasopism. Zdecydowanie na pierwszy plan wysunęło się tu zagadnienie antagonizmu na linii Rosja-Zachód oraz jego konsekwencje dla euroatlantyckiej architektury bezpieczeństwa. Interesującą analizę szerszego kontekstu obecnego kryzysu polityczno-militarnego w Europie Wschodniej i jego globalnych konsekwencji zaprezentował twórca teorii cyklów potegi prof. Charles F. Doran w artykule pt. Imperatives of European Security at Russia's Critical point on its Power Cycle, opublikowanym na łamach „Stosunków Międzynarodowych” (Doran, 2015). Naturalnie, w wyjaśnianiu obecnej sytuacji międzynarodowej autor tego artykułu posługuje się perspektywą neorealistyczną i postrzega ostatnie wydarzenia przez pryzmat cyklów potęi. W opinii prof. Dorana, destabilizacja ładu międzynarodowego wynika wprost z dokonującej się właśnie transformacji systemowej. Jest to sytuacja, w której kilka mocarstw równocześnie przekracza punkt krytyczny swojego cyklu potegi (wskazuje, iż obecnie dotyczy to ChRL, Japonii i Rosji). W konsekwencji dochodzi do zachwiania czterech tzw. „pewników polityki światowej” (są to: liczba graczy w systemie centralnym, ich relatywna potęga, przestrzeganie zasad gry oraz równowaga interakcji). Największą odpowiedzialność za te turbulencje ponosi zdaniem Ch. F. Dorana Rosja, gdyż to za jej sprawą doszło do pierwszego od 60 lat przypadku aneksji terytorium przez wielkie mocarstwo. Autor omawianego artykułu zauważa jednak, iż zarówno Rosja, jak i ChRL, promują koncepcję wielobiegunowego ładu światowego jako uzasadnienie dla ustanowienia swych wyłącznych stref wpływów.

Co interesujące w tym punkcie swej analizy, Ch. F. Doran zdaje się odwoływać do założeń perspektywy liberalnej, a nawet konstruktywistycznej. Twierdzi on bowiem, iż próby budowy stref wpływów podjęte zarówno przez Federację Rosyjska, jak i Chińską Republikę Ludową stanowią zewnętrzną projekcję autorytaryzmu ustrojów obu państw. Co więcej, wyjaśniając obecną politykę Rosji kładzie duży nacisk na przywództwo i preferencje polityczne Władimira Putina, który ma w ten sposób dążyć do zmiany biegu historii i zmiany pozycji Rosji względem pozostałych wielkich mocarstw. Umiejscowienie przynajmniej części przyczyn zmian systemowych na poziomie ustroju państwa lub nawet preferencji określonego przywódcy (czy raczej skupionej wokół niego elity władzy) jest zdecydowanie bliższe perspektywie liberalnej niż realiz- 
mowi strukturalnemu. Co więcej, Ch. F. Doran zauważa, iż za sprawą obu mocarstw „rewizjonistycznych” na arenę międzynarodową powraca tradycyjna koncepcja stref wpływów jako obszarów wyłącznej dominacji i podporządkowania, która nie mieściła się w obowiązującym do niedawna leksykonie liberalnego myślenia o stosunkach międzynarodowych. Nadto, w jego opinii, ,[...] państwa autorytarne usiłują wykorzystać wielobiegunowość jako bezpośrednie wyzwanie dla założeń otwartości i wymiany wyrażanych w liberalnym porządku handlowym i politycznym" (ibidem: 96). W zasadzie można by to uważać za uznanie znaczenia społecznej konstrukcji rzeczywistości stosunków międzynarodowych, a więc ponowne odwołanie do raczej dalekiej neorealizmowi perspektywy badawczej. Przytoczone wyżej przykłady świadczą o tym, iż mimo silnego osadzenia analizy Ch. F. Dorana w założeniach neorealistycznych, czerpie on pewne inspiracje $\mathrm{z}$ teorii liberalnych i konstruktywistycznych, co niewatpliwie służy pogłębieniu zrozumienia problemu.

Prof. Doran przedstawia dość pesymistyczną ocenę międzynarodowych konsekwencji omawianych procesów. W jego opinii reżim Władimira Putina konsekwentnie dąży do zmiany pozycji Rosji w ramach jej cyklu potegi, tzn. przejścia z dolnego punktu krytycznego do trajektorii wznoszącej. Konsekwencją takiego ruchu jest wzrost prawdopodobieństwa wybuchu wojny, gdyż ,gwaltowna zmiana strukturalna wytwarza wielką niepewność polityczną między wielkimi mocarstwami i w konsekwencji okazje do agresji” (ibidem: 94). Co więcej, autor omawianego artykułu zauważa, iż „[...] podczas gdy Rosja i Chiny popierają formułę wielobiegunowości, która pozwoliłaby im na przewagę w obrębie lokalnych stref wpływów, w rzeczywistości dokonują ekspansji na regiony globalne, tak szybko, jak tylko pozwala im wzrost zdolności wojskowych" (ibidem: 96). Jako przykłady takich działań pojawiają się operacje sił powietrznych i morskich obu państw na akwenach odległych od macierzystego terytorium. Pojawia się jednak pytanie, czy taka diagnoza nie jest stawiana nieco na wyrost. Operacje wojskowe obu mocarstw prowadzone poza obszarami, które one same uznają za własne strefy wpływów wciąż mają charakter ograniczony i raczej nieregularny. Zdolność obu państw (zwłaszcza ChRL) do długotrwałej projekcji istotnej siły wojskowej z dala od macierzystego terytorium wciąż jest poddawana w wątpliwość. Nie można wykluczyć, iż wysoce symboliczne działania chińskich i rosyjskich sił zbrojnych w odległych regionach globu (jak na przykład dalekodystansowe loty rosyjskich bombowców strategicznych) mają raczej charakter incydentalnych (lub powtarzanych nieregularnie) demonstracji i nie są preludium do stałej obecności na odległych akwenach. Naturalnie, rosyjska interwencja w Syrii prezentuje w tym zakresie zupełnie nową jakość, jednak wciąż ma charakter ograniczony i korzysta z zaplecza udostępnionego przez regionalnego sojusznika.

Niezwykle ważna obserwacja prof. Dorana dotyczy faktu, iż wzrost politycznych ambicji przywódców Federacji Rosyjskiej znacznie wyprzedził przyrost narodowej potęgi (głównie gospodarczej). Jak zauważa ten autor: „Rosja chce większej roli niż ta, którą uzasadnia poziom jej potegi. W perspektywie historycznej takie luki były bardzo destabilizujące" (ibidem: 99). Pozostaje zatem pytanie o działania, które wspólnota transatlantycka powinna podjąć w reakcji na te niekorzystne trendy. Udzielając na nie odpowiedzi, Ch. F. Doran zaczyna od stwierdzenia, iż państwa europejskie (w domyśle - europejscy członkowie NATO) od lat przeznaczają zbyt małe środki na cele obronne. 
W jego opinii wynika to z przyjęcia dwóch watpliwych (i jak pokazały wydarzenia ostatnich dwóch lat, w dłuższej perspektywie błędnych) założeń strategicznych. W pierwszym z nich przyjęto, iż intencje Rosji są przyjazne i w konsekwencji państwo to nie stanowi istotnego zagrożenia. W ramach drugiego uznano, iż w razie potrzeby zawsze można liczyć na wsparcie ze strony USA. Ch. F. Doran uważa, iż taka diagnoza środowiska bezpieczeństwa doprowadziło do rozprzestrzenienia się w NATO „syndromu gapowicza" (ang. free riding) i to w dwóch wymiarach - transatlantyckim (poleganie na amerykańskich gwarancjach bezpieczeństwa) oraz europejskim (przerzucanie odpowiedzialności na Francję i Wielką Brytanię - państwa zdolne i chętne do prowadzenia aktywnej polityki bezpieczeństwa). Problem atrofii europejskich zdolności wojskowych jest dodatkowo pogłębiany przez rozproszenie i dublowanie wydatków wojskowych we wszystkich 28 państwach sojuszu (każde z państw europejskich próbuje uzyskać podobne zdolności wojskowe samodzielnie). Prowadzi to do wysoce nieefektywnego wydatkowania $\mathrm{i}$ tak niewystarczających kwot przeznaczanych po wschodniej stronie Atlantyku na obronę.

Jako remedium prof. Doran postuluje integrację europejskich wydatków wojskowych (zebranie połowy budżetu obronnego każdego z europejskich członków NATO w osobnej puli dla realizacji wspólnych przedsięwzięć) oraz zapewnienie interoperacyjności wojsk europejskich z siłami USA. W jego opinii dopiero tak uzyskane zdolności pozwoliłyby na skuteczne odstraszanie Rosji i postawienie tamy jej agresywnej polityce. Propozycja ta, mimo swej niezaprzeczalnej logicznej spójności w ramach teorii cyklów potęgi, nie bierze chyba pod uwagę pewnych kwestii, na które więcej światła mogłyby rzucić podejścia liberalne i konstruktywistyczne. Nawet obecny, znacznie skromniejszy od proponowanego przez Ch. F. Dorana poziom integracji wojskowej w ramach NATO napotyka na ogromne przeszkody w postaci rozbieżności interesów państw członkowskich i ich dążenie do ochrony partykularnych interesów politycznych, gospodarczych, militarnych i symbolicznych. W obliczu problemów, o których w nadmiarze piszą autorzy kolejnych omawianych w tym przeglądzie artykułów (Dybczyński, 2015; Madej M., 2015) założenie, iż państwa członkowskie zdecydują się na oddanie połowy swych budżetów obronnych w zarząd wspólnotowy zdaje się przeceniać dojrzałość polityczną euroatlantyckiej wspólnoty politycznej.

Z konkluzjami tekstu prof. Dorana (szczególnie dotyczącymi pozycji Rosji w ramach cyklu potęgi) koresponduje sama w sobie bardzo interesująca analiza sytuacji ekonomicznej Federacji Rosyjskiej zaprezentowana przez Annę Madej w artykule pt. Sankcje i kontrsankcje. Przyczyny obecnego kryzysu ekonomicznego w Rosji zamieszczonym w kwartalniku „Bezpieczeństwo Narodowe” (Madej A., 2015). Przedstawiono w nim kompleksową diagnozę kondycji gospodarki rosyjskiej w 2014 r. Zamieszczone w tekście dane jasno świadczą, iż sytuacja nie jest tragiczna, ale co najmniej poważna. Świadczą o tym m.in.: ledwo zauważalny wzrost gospodarczy, ujemny wskaźnik inwestycji w środki trwałe, spadek eksportu ropy naftowej i gazu, mocne obniżenie kursu rubla, wysoka inflacja, zmniejszenie dochodów gospodarstw domowych i płac realnych (po raz pierwszy od 1999 r.) czy zmniejszenie rezerw walutowych o prawie 1/4 (w wyniku wysiłków na rzecz obrony wartości rubla) (ibidem: 104-107). Zdaniem autorki omawianego artykułu na taką sytuację gospodarki rosyjskiej złożyły się cztery zasadnicze czynniki: słaba koniunktura światowa, spadek cen ropy naftowej, niepewność 
inwestorów wywołana nałożeniem sankcji oraz problemy strukturalne. Co istotne, za kluczowe uznała problemy strukturalne, które zostały w pełni obnażone przez oddziaływanie pozostałych czynników. A. Madej wprost stwierdza, iż: „Rosja jest dotknięta syndromem holenderskim: wpływy z eksportu surowców zmniejszają motywację do wprowadzenia niełatwych i bolesnych dla społeczeństwa reform gospodarczych, wzrost dochodów społeczeństwa nie łączy się ze wzrostem produktywności i efektywności kapitału, co powoduje zmniejszenie konkurencyjności produktów i biznesu, a także umacnia walute, co negatywnie wpływa na eksport" (ibidem: 112). Taki stan rzeczy jest kumulacją lat niekorzystnych tendencji (czy wprost zaniedbań) w zakresie demografii, inwestycji infrastrukturalnych, innowacyjności i edukacji czy jakości zarządzania. Można przyjąć, iż rosyjskie państwo (i społeczeństwo) żyły ze swoistej „renty” zapewnianej przez wysokie ceny ropy naftowej. To na tym fundamencie została zbudowana względna stabilizacja i dobrobyt, na których w znacznej mierze (chociaż nie wyłącznie) opiera się legitymacja rządów Władimira Putina.

Nałożone przez USA, UE i szereg innych państw zaliczanych do tzw. Zachodu (jak Kanada czy Australia) w odpowiedzi na rosyjską agresję wobec Ukrainy, sankcje dodatkowo osłabily tą chwiejną konstrukcję, uderzając w kilka czulych punktów. A. Madej stwierdza, iż: „Sankcje i kontrsankcje uderzyły w rosyjską gospodarkę na cztery sposoby: wpłynęły na zamęt na rynku walutowym i deprecjację rubla, spowodowały gwałtowny odpływ kapitału, zablokowały dostęp do międzynarodowych rynków finansowych, doprowadzity do pogorszenia nastrojów konsumenckich" (bidem: 109). W tej sytuacji Rosja przyspieszyła oczekiwany od pewnego czasu ,gospodarczy zwrot ku Azji”, przede wszystkim intensyfikując wspólpracę gospodarczą z Chińską Republiką Ludową (czego najbardziej znamiennym przykładem był podpisany w maju 2014 r. gigantyczny wieloletni kontrakt na dostawy gazu ziemnego). Wnikliwie analizując strukturę handlu chińsko-rosyjskiego, autorka omawianego artykułu dochodzi do wniosku, iż „że rosyjsko-chińskie stosunki handlowe bardziej odpowiadają interesom Chin niż Rosji. Jeżeli tendencje te się utrzymają, to Rosja zostanie 'młodszym partnerem' Chin i dostawcą czystych surowców" (ibidem: 122). Taka sytuacja wynika z faktu, iż Rosja eksportuje do ChRL przede wszystkim surowce, podczas gdy Chiny w druga stronę wysyłają dobra przetworzone. Nie są jednak w stanie zastąpić partnerów zachodnich w obszarze nowoczesnych technologii (niezbędnych chociażby do kolejnych inwestycji w wydobycie ropy i gazu). A. Madej zauważa, iż wysoka komplementarność gospodarek chińskiej i rosyjskiej (z jednej strony zamożny inwestor - konsument energii, z drugiej jeden z największych na świecie producentów surowców energetycznych) nie przekłada się na głębsze zacieśnianie więzów gospodarczych z uwagi na brak zaufania politycznego między obu państwami i w konsekwencji niechęć do pogłębiania współzależności gospodarczych. Trudno się temu dziwić, wszak rola „młodszego partnera" gospodarczego supermocarstwa nie jest specjalnie pociągająca dla przywódców państwa postrzegającego siebie jako jedno $\mathrm{z}$ wiodących mocarstw światowych.

Przytoczone powyżej fakty mogłyby prowadzić do wniosku, iż zachodnie sankcje mogą tak skutecznie zaszkodzić rosyjskiej gospodarce, iż zmusi to przywódców Federacji do zmiany polityki na bardziej koncyliacyjną. Jednak A. Madej zwraca uwage, iż długoterminowy bilans sankcji pozostaje niepewny. Rosyjska gospodarka nie załamała się, a wprowadzone ograniczenia otwierają nawet pewne możliwości w zakresie roz- 
woju rodzimej produkcji czy nawiązywania relacji gospodarczych z nowymi partnerami. Na płaszczyźnie politycznej kluczowy wydaje się wpływ sankcji na postawy społeczeństwa rosyjskiego. Autorka omawianego artykułu jest raczej sceptyczna co do możliwości szybkiej utraty popularności przez obecnego prezydenta (budowanej na stabilizacji gospodarczej poprzednich lat oraz asertywnej polityce zagranicznej).

Patrząc na analizy Ch. F. Dorana i A. Madej, można wyciągną dwa szersze wnioski. Po pierwsze, największym beneficjentem obecnego antagonizmu na linii Rosja-Zachód jest ChRL. Wynika to nie tylko ze wzmocnienia pozycji przetargowej Pekinu w gospodarczych negocjacjach z Moskwą, ale także potencjalnego zaburzenia amerykańskiego militarnego ,zwrotu ku Azji” przez konieczność ponownego zaangażowania w sprawy bezpieczeństwa Europy. Pod drugie, istnieje duże prawdopodobieństwo dalszej eskalacji poziomu agresywności rosyjskiej polityki zagranicznej. Wynika to zarówno ze wskazanej przez Ch. F. Dorana luki między aspiracjami a realnym potencjałem rosyjskiej polityki, ale także tego, iż (co uwypukla analiza A. Madej) kolejne demonstracje stanowczości (czy wojowniczości) wobec świata zewnętrznego pozostały jednym z niewielu sposobów utrzymania poparcia społecznego, które pozostały do dyspozycji Władimira Putina (wobec co najmniej niepewnych perspektyw poprawy sytuacji gospodarczej).

Wydaje się, iż trafną zapowiedzią dalszych kroków rosyjskiej polityki jest uwaga A. Madej na temat Bliskiego Wschodu (wyrażona jeszcze przed wrześniem $2015 \mathrm{r}$.): „Niezmiennym decydującym czynnikiem dla Rosji pozostaje cena baryłki ropy. Znaczenie tego elementu wykracza poza sferę ekonomiczną, rzutując także na podejmowane w Moskwie decyzje dotyczące polityki zagranicznej, choćby związane z rosyjskim zaangażowaniem w kryzysy na Bliskim Wschodzie. Wyłączyć z gry znaczących konkurentów i podnieść przy tym cenę surowca - to marzenie kremlowskich decydentów" (ibidem: 125).

Kryzys w relacjach Rosja-Zachód wywołany rosyjską agresją wobec Ukrainy zmienił również parametry debaty na temat roli, zadań i kierunków rozwoju NATO. Z punktu widzenia polskiej polityki bezpieczeństwa, Sojusz Północnoatlantycki stanowi kluczową instytucję w ramach euroatlantyckiej architektury bezpieczeństwa. Nie może zatem dziwić fakt, iż kierunki jego dalszej ewolucji są przedmiotem ożywionej debaty wśród polskich badaczy spraw bezpieczeństwa międzynarodowego. W roku 2015 „Rocznik Strategiczny” opublikował dwa ważne artykuły dotykające tej tematyki, które wyrażają odmienne (choć kompatybilne) stanowiska w tej dyskusji. Prezentują je Rober Kupiecki (Obrona kolektywna NATO. Stała misja i zmienny kontekst strategiczny, 2015) oraz Andrzej Dybczyński (Przyszlość NATO, 2015). Jak zauważa drugi z wymienionych autorów, teksty te powstały w oparciu o różne podejścia badawcze. Analiza R. Kupieckiego opiera się na empirii, wspartej wieloletnią pracą w strukturach Sojuszu. Natomiast prognozy A. Dybczyńskiego zostały zbudowane na fundamencie teorii sojuszy, zastosowanej do analizy konkretnego przypadku NATO. W konsekwencji, oba teksty ciekawie się uzupełniają mimo, iż ich autorzy formułują odmienne wnioski.

Stanowisko R. Kupieckiego odzwierciedla pogląd dominujący w polskiej optyce postrzegania Sojuszu (zarówno tej politycznej, jak i w znacznej mierze naukowej). Podkreśla on mianowicie, iż ,kolektywna obrona określa sens istnienia Sojuszu 
Północnoatlantyckiego. Niezależnie od tego czy rozpatrywana w kontekście zimnowojennej działalności NATO, czy też po 1989 r., jest to unikatowa i jedyna niezbywalna misja organizacji” (Kupiecki, 2015: 313). W opinii Autora omawianego artykułu, kolektywna obrona odgrywa tu trzy zasadnicze role: zasadniczego instrumentu polityki bezpieczeństwa NATO, jedynej bezspornej płaszczyzny międzysojuszniczej komunikacji oraz źródła zdolności wojskowych, które stanowią również podstawę innych misji realizowanych przez Sojusz (ibidem: 313-314). W okresie pozimnowojennym popularne stało się przeciwstawianie kolektywnej obrony (tradycyjnej misji sojuszu) nowym obszarom jego działania (takim jak operacje reagowania kryzysowego czy inicjatywy bezpieczeństwa kooperatywnego). R. Kupiecki odrzuca taką dychotomię jako fałszywą. W jego opinii wszelkie nowe inicjatywy podejmowane przez Sojusz po 1989 r. (takie jak: rozszerzenie, podjęcie misji ekspedycyjnych, rozszerzenie działalności na nowe sfery bezpieczeństwa czy budowa sieci partnerstwa dla bezpieczeństwa kooperatywnego) były w istocie realizacją obrony kolektywnej za pomocą innych środków, lepiej odpowiadających odmiennemu środowisku bezpieczeństwa. R. Kupiecki z jednoznaczną aprobatą odnosi się do ustaleń szczytu NATO w Newport, który w odpowiedzi na agresywną politykę Federacji Rosyjskiej zaakceptował szereg posunięć (większość z nich w ramach Planu Gotowości - ang. Readiness Action Plan), które ponownie stawiają kolektywną obronę terytorium sojuszniczego w centrum aktywności Sojuszu. Podsumowując, wnioski przedstawione przez tego Autora można dojść do wniosku, iż oczekuje on swoistego „powrotu do korzeni” i przywrócenia charakteru oraz kształtu NATO zbliżonego do tego, który występował w trakcie zimnej wojny.

A. Dybczyński postrzega perspektywy przyszłości NATO cokolwiek inaczej. Jego artykuł stanowi intrygującą próbę prognozy kierunku przyszłej ewolucji Sojuszu. Wychodząc od trzech głównych, kształtujących ją zmiennych: kontekstu strategicznego (czynnik zewnątrzsojuszniczy), oddziaływania między członkami (czynnik wewnątrzsojuszniczy) oraz interesów członków (czynnik narodowy), kreśli on trzy scenariusze. Pierwszy - rewitalizacja - sprowadza się do postulowanego przez R. Kupieckiego odtworzenia NATO jako klasycznego sojuszu obronnego skupionego na zadaniu kolektywnej obrony. Jego przeciwieństwem jest scenariusz tranzycji, sprowadzający się do przekształcenia Organizacji w reżim międzynarodowy, przez zanik kolektywnej obrony na rzecz innych instrumentów kształtowania bezpieczeństwa międzynarodowego (jak operacje reagowania kryzysowego czy instrumentarium bezpieczeństwa kooperatywnego). Najbardziej intrygujący (i zarazem kontrowersyjny) jest scenariusz pośredni. Zakłada on rekonstrukcję rozumianą jako nieformalny i dynamiczny podział NATO na dwie grupy członków: sprzymierzeńców i satelitów.

A. Dybczyński za najbardziej prawdopodobny uważa właśnie scenariusz rekonstrukcji, za to najmniejsze szanse realizacji przyznaje rewitalizacji. Wynika to z przenikliwej analizy wewnętrznej sytuacji Sojuszu. Odwołując się do twierdzeń R. Kupieckiego, autor omawianego artykułu zauważa, iż kolektywna obrona nie jest wcale samoistnym fundamentem NATO. Mimo jej niezaprzeczalnego znaczenia, zasadniczy punkt oparcia dla całej konstrukcji stanowi wspólny interes członków. W opinii A. Dybczyńskiego to właśnie tej substancji dotknął najpoważniejszy kryzys. Państwa członkowskie są podzielone $z$ uwagi na rozbieżne interesy, jak również oceny środowiska bezpieczeństwa, dodatkowo mamy do czynienia z dużym zróżnicowaniem potencjałów wojsko- 
wych i (co może nawet bardziej istotne) gotowości do ich użycia. Obecny trend w stronę (względnej) rewitalizacji jest efektem agresywnych działań Rosji w ramach konfliktu ukraińskiego, które rozbudziły poczucie zagrożenia w wielu państwach NATO. Analiza A. Dybczyńskiego jasno pokazuje jak nieskuteczne są działania Federacji Rosyjskiej. Kolejne zbrojne prowokacje wobec członków i partnerów NATO (jak choćby: państwa bałtyckie, Szwecja, Finlandia czy Turcja) jedynie wzmagają obawy sojuszników i wzmacniają ich poparcie dla wspólnego przeciwdziałania. Jak trafnie zauważa Autor, Rosja zawsze była kontekstem strategicznym NATO, w tym sensie, iż sojusznicza polityka bezpieczeństwa była i jest funkcją stosunków z tym państwem. W rezultacie, tak jak rosyjska agresywność popchnęła NATO w stronę rewitalizacji, tak samo zmiana rosyjskiej polityki (czy raczej taktyki jej realizacji) może odwrócić tą tendencję. Chociaż, jak zauważa sam A. Dybczyński, perspektywy trwałej zmiany celów i stylu uprawiania rosyjskiej polityki są niezbyt zachęcające, to jednak sama zmiana taktyki mogłaby wzmocnić te głosy na Zachodzie, które dążą do „wyciszenia antagonizmu" i choćby częściowego powrotu do „business as usual” sprzed 2014 r. W zasadzie obecnie możemy obserwować próbę zastosowania takiej taktyki w formie swoistego „wygaszania” zbrojnej fazy konfliktu ukraińskiego oraz ofert współpracy z Zachodem w zwalczaniu innego, ale za to wspólnego wroga (tzw. Państwo Islamskie). W takiej sytuacji Dybczyński nie wyklucza możliwości powrotu NATO do dryfu w stronę tranzycji w reżim międzynarodowy.

Największe zainteresowanie (ale również kontrowersje) budzi natomiast scenariusz rekonstrukcji. Zakłada on, iż dla poprawy efektywności funkcjonowania NATO pożądane byłoby nieformalne wprowadzenie dwóch kategorii członkostwa w tej organizacji. Grupa określana mianem „sojuszników” składała by się z państw zdolnych i skłonnych do wypełniania wszystkich obowiązków sojuszniczych (z obroną kolektywną na czele) oraz ponoszenia kosztów z tym związanych. Tymczasem tzw. satelici to państwa niechętne lub niezdolne do pełnego uczestnictwa w mechanizmach obrony kolektywnej NATO (w domyśle, niepodzielające oceny co do wzrostu zagrożenia ze strony Rosji). Na mocy proponowanych zmian „satelici” zostaliby niejako ,zwolnieni” z konieczności wykonywania wszystkich zobowiązań sojuszniczych, ale wiązałoby się to również z ograniczeniem sojuszniczych gwarancji bezpieczeństwa wobec nich. W opinii A. Dybczyńskiego, takie rozwiązanie przyniosłoby Sojuszowi szereg korzyści: zwiększenie wiarygodności gwarancji sojuszniczych (skupienie wysiłków obronnych na tych obszarach, gdzie zagrożenie jest faktycznie odczuwane i podejmowanie ich jedynie przez państwa do tego gotowe i chętne); zwiększenie przewidywalności działań NATO (tak zewnętrznej, jak i wewnętrznej); uznanie rzeczywistości, w której zróżnicowany status bezpieczeństwa członków jest faktem; stworzenie mechanizmu swoistej ,socjalizacji” skłaniającej ,satelity" do przywrócenia pełnego członkostwa oraz większą elastyczność przyjmowania nowych członków (można by im udzielić „słabszych" gwarancji).

Propozycja ta jest niewątpliwie ciekawa, a jej największą zaletą (jak podkreśla sam jej autor) jest zerwanie z fikcją spójnego i solidarnego Sojuszu na rzecz uznania rzeczywistości, w której część członków nie chce w pełni włączać się w rewitalizację kolektywnej obrony (z uwagi na różnice interesów, potencjałów czy gotowości ich użycia). Nie sposób jednak nie zauważyć wielu wyzwań (czy wręcz niebezpieczeństw) związa- 
nych z jej możliwą implementacją. Przede wszystkim (jak zauważa sam A. Dybczyński) oznacza to de facto likwidację zasady solidarności sojuszniczej i tak cenionej „niepodzielności bezpieczeństwa obszaru eurotlantyckiego”. Uznanie czéści członków NATO za de facto sojuszników drugiej kategorii może bardzo szybko przekształcić się w alienację tych państw i totalną atrofię współpracy polityczno-wojskowej między nimi. Warto też zadać pytanie, o to, w jaki dokładnie sposób miało by zostać przeprowadzone rozróżnienie na „sojuszników” i „satelitów”. Autor omawianego artykułu przyznaje, iż redefinicja zobowiązań sojuszniczych musiałaby nastạpić na drodze ustaleń nieformalnych (trudno sobie przecież wyobrazić, aby takie zapisy znalazły się w traktacie). Co więcej, nie bardzo wiadomo co w praktyce miałyby oznaczać „słabsze gwarancje sojusznicze" dla,,satelitów". Czy w takim razie te państwa nie byłyby objęte zobowiązaniem do wspólnej obrony na bazie art. 5? Jaka byłaby zatem dla nich wartość pozostawania członkami NATO (poza symboliczno-polityczna)? Bardzo trudno byłoby to rozstrzygnąć, zwłaszcza na poziomie mechanizmów nieformalnych. W efekcie zamiast spodziewanego ,zwiększenia przewidywalności działań NATO” mógłby nastappić efekt dokładnie odwrotny.

Kolejny poważny problem to pytanie o podział obecnych członków na dwie zaproponowane grupy. Z przedstawionej przez A. Dybczyńskiego analizy jasno wynika, iż aby ta reforma NATO osiągnęła zakładane efekty w grupie „sojuszników” powinny się znaleźć państwa o dużym potencjale wojskowych (zdolne do skutecznej realizacji kolektywnej obrony) natomiast w gronie ,satelitów” miałyby przeważać małe i słabe państwa niezdolne (i być może niechętne) do podejmowania takich ciężarów. Tymczasem współczesna sojusznicza rzeczywistość jest taka, iż faktyczną rewitalizacją kolektywnej obrony najbardziej zainteresowane są państwa najsłabsze (takie jak państwa bałtyckie), natomiast niektóre silne państwa (jak Francja i Niemcy) mają do tego co najmniej ambiwalentny stosunek. W efekcie warto rozważyć scenariusz, w którym w grupie „satelitów" znajdują się stosunkowo silne państwa (np. Francja, Niemcy, Hiszpania, Włochy) natomiast ciężar pełnej kolektywnej obrony spoczywa na mniejszym gronie „sojuszników" złożonym głównie z mniejszych państw Europy Wschodniej (być może coraz bardziej uzależnionych od dwustronnych gwarancji bezpieczeństwa udzielanych przez Wielką Brytania i przede wszystkim USA). Wątpliwości te nie zmieniają jednak faktu, iż analiza A. Dybczyńskiego jest bardzo przenikliwa, a jej najsilniejszą stroną jest twarda ocena rzeczywistości w oparciu o jasne założenia teoretyczne.

Obok dyskusji nt. przyszłości NATO na łamach polskiej prasy naukowej o tematyce bezpieczeństwa międzynarodowego pojawia się również temat Wspólnej Polityki Bezpieczeństwa i Obrony UE. Artykuł Marka Madeja pt. Spóźniony (i krótkotrwaly) entuzjazm. Polska wobec Wspólnej Polityki Bezpieczeństwa i Obrony w latach 2008-2014 (zamieszczony na łamach czasopisma „Stosunki Międzynarodowe”) stanowi zwięzłe i kompetentne podsumowanie stanowiska Polski wobec tego zagadnienia. Jednocześnie w kolejach „,polskiej przygody z WPBiO” jak w soczewce odbijają się szersze problemy tej inicjatywy. M. Madej wyróżnia dwa zasadnicze etapy polskiego zaangażowania w wysiłki na rzecz budowy „europejskiej obrony” (od ok. dwóch lat jesteśmy w trakcie trzeciego, jeszcze niedookreślonego etapu). W okresie od 1999 r. (formalne powołanie Europejskiej Polityki Bezpieczeństwa i Obrony) do 2007 r. (objęcie władzy w Polsce przez koalicję PO-PSL) polska polityka znajdowała się w fazie ,atlantyzmu 
(wolno) reformowanego". Bez trudu można uzasadnić tezę, iż wówczas NATO postrzegano jako najważniejszego gwaranta bezpieczeństwa Polski, a na unijne inicjatywy patrzono $\mathrm{z}$ pewną podejrzliwością. Wynikało to $\mathrm{z}$ obecnych w NATO obaw odnośnie tzw. 3xD (ang. decoupling, duplication, discrimination), skupienia EPBiO na misjach ekspedycyjnych (a brak mechanizmów wspólnej obrony, które Polskę najbardziej interesowały) oraz właściwie brak zainteresowania w ramach tej polityki wschodnią czéścią Europy. Zdaniem M. Madeja zaangażowanie Polski w EPBiO w tamtym okresie miało głównie charakter demonstracji sojuszniczej solidarności mającej na celu utrzymanie dobrych relacji z kluczowymi partnerami (jak np. z Francją w kontekście misji EUFOR Chad/RCA).

Utworzenie pierwszego rządu Donalda Tuska wyznacza początek drugiej fazy polskiego zaangażowania w EPBiO/WPBiO, którą M. Madej określa jako: „czas entuzjazmu (spóźnionego, umiarkowanego i ostatecznie chwilowego)". W tym czasie Polska przedstawiła szereg propozycji (jak np. inicjatywa chobylińska czy postulaty polskiej prezydencji w Radzie UE), które zmierzały w stronę wzmocnienia WPBiO i nadania jej silnego wymiaru operacyjnego. Autor omawianego artykułu upatruje przyczyn tej „zmiany kursu” w dwóch zasadniczych czynnikach. Po pierwsze, ponownie kwestie współpracy w dziedzinie bezpieczeństwa stały się polem dla okazywania unijnym partnerom znaczenia integracji europejskiej dla polskiego państwa i konkretnego rządu. W tym kontekście warto zauważyć, iż zwłaszcza w pierwszych latach urzędowania gabinet D. Tuska wykazywał tendencję do pewnego dystansowania się od polityki USA i chęci odbudowy dobrych relacji z kluczowymi partnerami unijnymi (jak Francja czy Niemcy), także jako zaprzeczenia polityce poprzedników. Wypływało to również z drugiego czynnika, którym było (dość powszechne w Polsce) rozczarowanie kierunkiem ewolucji NATO w tamtym okresie. Sojusz ewidentnie przyznawał priorytet misjom ekspedycyjnym (kosztem drogiej Polsce kolektywnej obrony). Jednocześnie kluczowy sojusznik - USA - wycofał się w 2009 r. z ambitnych planów budowy w Polsce instalacji obrony przeciwrakietowej, w zamian proponując mniej ambitny i rozłożony $\mathrm{w}$ czasie projekt. W Polsce odebrano to jako afront i uległość wobec presji rosyjskiej. Stąd żywa stała się idea ,,podwójnej polisy” bezpieczeństwa (NATO i UE). Nowy kurs europejski zmierzał właśnie w stronę wzmocnienia polisy unijnej dla zrekompensowania postrzeganego osłabienia polisy transatlantyckiej. Stąd też Polska próbowała ukierunkować ewolucję WPBiO w stronę rozwoju kolektywnej obrony.

Wysiłki te nie przyniosły jednak oczekiwanych rezultatów. Powodem była niechęć szeregu państw członkowskich (w tym Wielkiej Brytanii), a także kryzys gospodarczy przełomu dekad, który doprowadził do minimalizacji nie tylko budżetów, ale także ambicji wojskowych w większości państw europejskich. Symbolicznym końcem tego okresu jest rok 2013. Właśnie wtedy doszło do szczytu Rady Europejskiej, którego głównym tematem miał być rozwój WPBiO. Mimo dużych oczekiwań ze strony państw członkowskich, rezultaty były bardzo ograniczone. Co jeszcze bardziej istotne, $2013 \mathrm{r}$. przyniósł początek kryzysu ukraińskiego, który (zwłaszcza po przekształceniu w otwarty konflikt zbrojny) obnażył bezsilność WPZiB i umocnił pozycję NATO jako jedynej wiarygodnej instytucji zdolnej do zapewnienia swoim członkom „twardego" bezpieczeństwa militarnego. Wydaje się zatem, iż w polskiej polityce mamy do czynienia $\mathrm{z}$ powrotem do atlantyzmu. 
Analiza dokonana przez M. Madeja pozwala na wyciągnięcie szerszych wniosków nt. dalszej ewolucji WPBiO. W końcu podejrzliwość, frustracja i zawiedzione nadzieje związane $\mathrm{z}$ tą inicjatywą nie są jedynie udziałem Polski. Można zaryzykować tezę, iż dla większości państw unijnych zaangażowanie w budowę WPBiO w dużej mierze opierało się na szczytnej retoryce, za którą nie nadążały realne działania. Dodatkowo, współpraca unijna była najczęściej traktowana jako „opcja drugiego wyboru” w stosunku do NATO (np. Wielka Brytania, Polska) lub działań unilateralnych (Francja). Realne efekty osiagano tam, gdzie służyło to interesom dużych państw członkowskich (operacje ekspedycyjne na obszarze Franceafrique) lub gdzie dostrzegano duże korzyści w relacji koszt-efekt (współpraca technologiczno-przemysłowa). W tej sytuacji można postawić pytanie o sens rozwijania WPBiO jako instrumentu wspólnej obrony lub militarnego reagowania kryzysowego, w sytuacji gdy wydaje się, iż większość państw członkowskich po prostu nie uznaje tego za potrzebne. Może zatem bardziej obiecująca byłaby współpraca ograniczona do sfery techniczno-przemysłowej (EDA, integracja rynku uzbrojenia) oraz niemilitarnego reagowania kryzysowego (np. jako uzupełnienia NATO w reakcji na zagrożenia hybrydowe).

Jednym z tematów najczęściej dyskutowanych w 2015 r. była tzw. wojna hybrydowa. Pojęcia tego szeroko używano dla określenia rosyjskich działań wobec Ukrainy. Chociaż koncepcja ta jest użyteczna dla analizy ewolucji współczesnych konfliktów zbrojnych, to jednak samo pojęcie jest mocno niedoprecyzowane i często jego interpretacja jest oparta na analizie jednego przypadku (Ukrainy). Niemniej, pojęcie wojny hybrydowej na trwałe weszło do słownika oficjalnych dokumentów strategicznych (chociażby NATO i UE), a także upowszechniło się w świadomości opinii publicznej. Temat ten w naturalny sposób stał się przedmiotem zainteresowania polskich badaczy bezpieczeństwa międzynarodowego. Na uwagę zasługuje tekst Mariusza Fryca Polska strategia obronności wobec zagrożenia militarnego z elementami „, wojny hybrydowej”, opublikowany przez „Bezpieczeństwo Narodowe”. Autor dokonuje w nim analizy aktualnej polskiej strategii obronności (wyznaczanej przez tzw. doktrynę Komorowskiego; szerzej: Fryc, 2014) z punktu widzenia przeciwdziałania zagrożeniom o charakterze hybrydowym.

Odwołując się do doświadczeń konfliktu ukraińskiego, M. Fryc charakteryzuje współczesną rosyjską sztukę strategiczną jako posługującą się dopasowaną do okoliczności kombinacją instrumentów zbrojnych (regularnych i nieregularnych), dyplomatycznych, ekonomicznych i propagandowych. Zasadniczym celem działań nie jest tu fizyczne zniszczenie sił zbrojnych przeciwnika, ale raczej erozja woli oporu po stronie całego atakowanego społeczeństwa. Ten kierunek myślenia zasadniczo odpowiada najczęstszemu sposobowi definiowania wojny hybrydowej. Warto jednak w tym miejscu zaznaczyć, iż sama koncepcja teoretyczna wojny hybrydowej jest sama w sobie jeszcze nie rozwinięta. Co więcej, w Polsce i szerzej na Zachodzie przyjęło się uważać, iż Federacja Rosyjska opracowała i wdrożyła kompleksową strategię hybrydową, która może zostać w przyszłości zastosowana przeciwko państwom członkowskim NATO. Jak zwraca uwagę chociażby Samuel Charap (Charap, 2015) może to być pewna nadinterpretacja. Nie zmienia to jednak faktu, iż siły Sojuszu Północnoatlantyckiego, w tym Siły Zbrojne RP, muszą uwzględniać nowe (lub na nowo odkryte) formy działań zbrojnych w swojej strategii i przygotowaniach obronnych. 
M. Fryc wskazuje na cztery zasadnicze elementy kształtującej się od kilku lat polskiej doktryny obronnej, które mają szczególne znaczenie dla obrony przed zagrożeniami hybrydowymi. Sa to kolejno: zdolności do wiarygodnego, militarnego odstraszania (zniechęcania) potencjalnego przeciwnika; potencjał przeciwzaskoczeniowy; zdolności do wykonania manewru strategicznego oraz projekcji siły oraz system kontr-dostępnościowy, tj. system strategicznej odporności kraju na agresję zbrojną. Całość składa się na spójną i logicznie powiązaną koncepcję strategiczną zmierzającą do zniechęcenia potencjalnego przeciwnika do ataku, a w wypadku agresji jej powstrzymania/odparcia we współpracy z siłami sojuszniczymi. Wydaje się, iż najmocniejszymi stronami tej doktryny jest elastyczność przewidywanej reakcji na hybrydowe i wysoce zmienne zagrożenia, budowa potencjału narodowego zdolnego do wstępnej reakcji wobec powolności (czy możliwego paraliżu) systemu decyzyjnego NATO oraz postawienie na innowacyjne rozwiązania techniczne i organizacyjne (jak np. systemy uderzeniowe dalekiego zasięgu). Naturalnie nie brakuje jednak wątpliwości co do efektywnej możliwości realizacji niektórych elementów tej doktryny. Skuteczne odstraszanie agresji ze strony mocarstwa nuklearnego przez państwo nienuklearne jest zawsze problematyczne. Również w przypadku Polski poddawano w wątpliwość realne możliwości planowanego potencjału odstraszania. Otwarte pozostaje również pytanie o ostateczny kształt tego co określa się mianem ,systemu kontr-dostępowego" (Fryc, 2015: 77) a więc w zasadzie nieregularnych form obrony własnego terytorium w oparciu o wojska specjalne i obronę terytorialną. Niewątpliwie jednak artykuł M. Fryca zarysowuje główne punkty koncepcji strategicznej, która zapewne w najbliższych latach stanie się obiektem żywej debaty w Polsce i szerzej w Sojuszu Północnoatlantyckim.

Kluczowe tendencje w międzynarodowym środowisku bezpieczeństwa 2015 r. to jednak nie tylko kwestia Rosji oraz jej antagonizmu wobec NATO. Inną interesująca tendencją (dostrzegalną już od kilku lat) jest wzrost rywalizacji mocarstw na obszarach strategicznych akwenów oceanicznych i towarzyszące mu napięcia. Ciekawym ujęciem tego problemu jest koncepcja ,morza Eurazjatyckiego" przedstawiona przez Jonathana Holslaga w 2013 r. (Holslag, 2013). Autor ten uznał, iż: „kontynent euroazjatycki stał się prawdziwą wyspą światową. [...] Równocześnie, morza opływające wyspę światową stały się jedną, zatłoczoną, obwodnicą morską, kluczowym kanałem dla handlu surowcami i towarami przemysłowymi oraz projekcji wpływu. [...] Wody te wyewoluowały z zestawu osobnych mórz w morską obwodnicę: prawdziwe Morze Eurazjatyckie" (ibidem: 155-156). Warto przytoczyć tę koncepcję, gdyż umożliwia ona nowe spojrzenie na dwa regiony morskie będące przedmiotem analizy polskich badaczy w 2015 r. Jakub Zajączkowski zwraca swą uwagę na Ocean Indyjski (Strategie morskie Indii, Chin i USA w regionie Oceanu Indyjskiego: analiza w kategoriach realizmu ofensywnego - „Stosunki Międzynarodowe”, 2015), podczas gdy Zdzisław Śliwa (Militaryzacja Arktyki - Federacja Rosyjska zaznacza obecność wojskowa $w$ regionie „Bellona”, 2015) analizuje rosyjską obecność wojskową w Arktyce.

J. Zajączkowski wskazuje, iż strategiczne znaczenie regionu Oceanu Indyjskiego wypływa z faktu, iż przepływa przez niego $2 / 3$ ruchu morskiego (ponad połowa ropy naftowej i 1/3 towarów transportowanych droga morska) (Zajączkowski, 2015: 46). $\mathrm{Z}$ punktu widzenia bezpieczeństwa międzynarodowego istotne jest również to, iż w ostatnich latach stał się on areną rywalizacji trzech mocarstw: Chińskiej Republiki 
Ludowej, Indii oraz Stanów Zjednoczonych. Autor omawianego artykułu jako podstawę teoretyczną swej analizy przyjął realizm ofensywny, uzasadniając to przydatnością tego podejścia dla analizy działań wielkich mocarstw oraz parametrów potęgi. Najogólniej rzecz biorąc, realizm ofensywny zakłada, iż w anarchicznym systemie międzynarodowym potęga staje się dla państw celem samym w sobie, $z$ uwagi na to, iż jest jedynym środkiem umożliwiającym przetrwanie. Ponieważ dhugofalowa kalkulacja adekwatnej potęgi (gwarantującej przetrwanie i autonomię) nie jest możliwa, zakłada się, iż wszyscy aktorzy będą dążyli do jej maksymalizacji za wszelką cenę, aż do poziomu hegemonii. W kontekście regionalnych kompleksów bezpieczeństwa o morskim charakterze (czyli większości współcześnie występujących) prowadzi to do sytuacji, w której mocarstwa regionalne dążą do zdominowania swojego regionu. Jest to sprzeczne $\mathrm{z}$ interesami mocarstw pozaregionalnych, które dążą do zachowania swobody manewru (i projekcji siły) na kluczowych akwenach, co m.in. pozwala im szachować posunięcia potencjalnych hegemonów regionalnych.

J. Zajączkowski przekłada te założenia teoretyczne na sytuację w regionie Oceanu Indyjskiego. Można tu zauważyć rosnącą rywalizację militarną Indii i Chin motywowaną dążeniem do zachowania lub rozszerzenia własnych stref wpływów. Indie zdają się być naturalnym pretendentem do roli hegemona w regionie. Zagraża temu jednak rosnąca obecność ChRL na Oceanie Indyjskim (przejawiająca się m.in. obecnością zespołów floty wojennej czy rozbudową sieci komercyjnych instalacji brzegowych i potencjalnych punktów bazowania floty - tzw. lańcucha peref). Działania te motywowane są chińskimi dylematami związanymi z uzależnieniem od szlaków żeglugowych biegnących przez ten akwen, którymi płynie większość importowanej przez ChRL ropy naftowej. Stąd teza, iż chińskie dążenie do hegemonii w Azji Wschodniej (i szerzej basenie Zachodniego Pacyfiku) nie może zostać zrealizowane bez zapewnienia silnej pozycji na Oceanie Indyjskim, celem zabezpieczenia swobody żeglugi dla własnej bandery. Trzecim bokiem tego strategicznego trójkąta są Stany Zjednoczone, które postrzegaja swobodę żeglugi (tak wojskowej, jak i cywilnej) jako jeden z fundamentów swojej supermocarstwowej pozycji. Dlatego też otwarcie sprzeciwiają się chińskim aspiracjom do hegemonii regionalnej. Prowadzi to do zacieśniania współpracy USA i Indii. Chociaż teoretycznie Indie powinny być przeciwne silnej obecności jakiegokolwiek mocarstwa zewnętrznego na obszarze Oceanu Indyjskiego, to jednak w praktyce zdają się dostrzegać, iż współpraca z USA jest konieczna dla zrównoważenia potegi chińskiej. $\mathrm{Na}$ marginesie, ciekawe jest pytanie, czy obecne zbliżenie amerykańsko-indyjskie będzie na tyle silne, aby przetrwać hipotetyczne wycofanie lub wyparcie wpływów chińskich z Oceanu Indyjskiego. Czy wówczas regionalna potęga zwróci ostrze swej strategii bezpieczeństwa przeciwko wpływom potęgi zewnętrznej? To pytanie pozostaje otwarte i mocno wybiega poza ramy tego opracowania.

J. Zajączkowski konkluduje, iż relacje Chiny-Indie-USA konstytuują obecnie region Oceanu Indyjskiego. Wynika to $\mathrm{z}$ faktu, iż „w strukturze oddziaływań wewnątrz regionalnych dominują relacje z udziałem tych trzech mocarstw" (ibidem: 69). W opinii Autora omawianego artykułu te trzy mocarstwa determinują w znaczny sposób dynamikę regionalnego systemu bezpieczeństwa, ponieważ stoją w obliczu dylematu bezpieczeństwa. Zdaje się to potwierdzać założenia realizmu ofensywnego, które wskazują na nieunikniony charakter antagonizmu i będący jego efektem wyścig zbro- 
jeń morskich. Co ciekawe, J. Zajączkowski uznaje, konflikt zbrojny z udziałem trzech omawianych mocarstw za mało prawdopodobny (przynajmniej w perspektywie krótkoterminowej). Zwraca uwagę, iż trilateralny układ Chiny-Indie-USA stabilizuje region, a wszystkie jego strony łączy wszechstronna współpraca polityczna i gospodarcza. Teza ta jest zaskakująca w kontekście całości artykułu, w którym konsekwentnie podkreślano antagonizm między mocarstwami i ich rywalizację militarna.

Z kolei na łamach „Bellony” Z. Śliwa podejmuje analizę roli Arktyki w strategii militarnej Federacji Rosyjskiej. Zwraca on uwagę, iż w aktualnej Doktrynie Wojskowej FR ,zabezpieczenie narodowych interesów w Arktyce" uznano za jedno z kluczowych zadań Sił Zbrojnych w czasie pokoju (Śliwa, 2015: 38). Już od kilku lat rosyjskie siły zbrojne realizują te wytyczne przez takie inicjatywy jak np. powołanie Połączonego Dowództwa Strategicznego Floty Północnej, wzmocnienie i modernizacja kontyngentów morskich, powietrznych i lądowych w tym regionie, czy reaktywacja sieci baz wojskowych w Arktyce. Z. Śliwa upatruje motywacji tych działań w szansach ekonomicznych, które otwierają się w tym regionie w raz ze zmianami klimatycznymi. Od dłuższego czasu żywo dyskutuje się perspektywy uzyskania dostępu do bogatych złóż surowców naturalnych ukrytych obecnie pod pokrywą lodową. Dodatkowo, spodziewane jest otwarcie tzw. Przejścia Północno-Wschodniego, stanowiącego krótszą drogę z Azji Wschodniej do Europy przez wody Oceanu Arktycznego (wzdłuż północnych wybrzeży Federacji Rosyjskiej). Autor omawianego artykułu wyraźnie akcentuje, iż zmiany te najprawdopodobniej doprowadzą do nasilenia rywalizacji między Rosją a państwami NATO (np. USA, Kanada, Norwegia). Decydują o tym nierozstrzygnięte spory terytorialne, jak również rosnące zainteresowanie wszystkich stron wzmożeniem aktywności gospodarczej i militarnej na nowo dostępnym akwenie.

Artykuł Z. Sliwy niewatpliwie zwraca uwagę na bardzo istotne zagadnienie. Topnienie lodów Arktyki faktycznie prowadzi do swoistej (choć ograniczonej) „gorączki” projekcji siły i deklaracji zainteresowania tym regionem. Nie ma najmniejszych wątpliwości, iż Federacja Rosyjska traktuje Arktykę jako jeden z regionów o strategicznym znaczeniu dla swego bezpieczeństwa. Warto jednak zwrócić uwagę na szerszy kontekst geopolityczny tych procesów. Po pierwsze, nie ma pewności co do tego, kiedy klimat Arktyki ociepli się na tyle, aby umożliwić regularną, bezpieczną i opłacalną aktywność ekonomiczną na tym obszarze (wydobywczą czy żeglugowa). Po drugie, możemy obserwować sporo inicjatyw zainteresowanych państw w dziedzinie współpracy na tym obszarze (jak chociażby rozwiązanie rosyjsko-norweskiego sporu o delimitację obszarów morskich czy joint venture BP i Rosnieftu dla eksploatacji złóż Dalekiej Północy). W końcu po trzecie, należy postawić pytanie o atrakcyjność potencjalnego Szlaku Północno-Wschodniego dla międzynarodowej żeglugi.

Z pomocą przychodzi tu, przywołana wcześniej, szersza koncepcja Morza Eurazjatyckiego Holslaga. Arktyczne szlaki żeglugowe miałyby stanowić alternatywę dla obecnych korytarzy morskich biegnących przez Zachodni Pacyfik, Ocean Indyjski i Morze Śródziemne. Wydaje się jednak, iż np. z punktu widzenia ChRL (jako potencjalnego beneficjenta takiego rozwiązania) rodzą się dwa problemy, jeden ekonomiczny, drugi strategiczny. Z punktu widzenia ekonomii, Przejście Północno-Wschodnie pozwala zaoszczędzić czas. Jednak warto zwrócić uwagę na fakt, iż trasa wzdłuż południowych brzegów Eurazji przebiega w pobliżu wybrzeży wielu dynamicznie 
rozwijających się ekonomicznie państw. Stwarza to możliwość korzystnej wymiany i współpracy gospodarczej z szerokim wachlarzem partnerów. Tymczasem szlak północny biegłby w większości wśród bezludnych i ekonomicznie nieaktywnych obszarów, ograniczając właściwie całe przedsięwzięcie do żeglugi z Azji Wschodniej do Europy, bez żadnych perspektyw na wizytę $w$ ekonomicznie atrakcyjnych punktach pośrednich. Co więcej, z perspektywy strategicznej, szlak arktyczny znajdowałby się pod całkowitą kontrolą jednego państwa - Federacji Rosyjskiej. Można zatem postawić pytanie: czy ChRL po to stwarza sobie alternatywę dla potencjalnie zdominowanych przez USA i Indie szlaków przez Ocean Indyjski, żeby zdać swoją żeglugę na łaskę (i nie łaskę) innego mocarstwa? Wydaje się, iż chińscy decydenci myślą właśnie w tym kierunku, rozwijając ambitny projekt ,jednego pasa i jednej drogi”. W końcu czy ChRL inwestowałaby miliardy dolarów w rozbudowę infrastruktury transportowej (morskiej i lądowej) wzdhuz południowych wybrzeży Eurazji oraz przez środek tego kontynentu, gdyby poważnie rozważała przerzucenie swej żeglugi na Ocean Arktyczny?

Podsumowując dokonany na potrzeby tego artykułu przegląd polskiej prasy naukowej w tematyce bezpieczeństwa międzynarodowego można zwrócić uwagę na dwie tendencje. Po pierwsze poważne turbulencje $w$ aktualnym międzynarodowym środowisku bezpieczeństwa przełożyły się na istotne ożywienie i ubogacenie debaty nt. szeregu kwestii bezpieczeństwa międzynarodowego. Problematyka ta wyraźnie pojawiła się w centrum zainteresowania, nie tylko środowiska naukowego, ale także decydentów politycznych i szerzej opinii publicznej. Tworzy to dobrą prognozę dla rozwoju studiów strategicznych w Polsce (i nie tylko). Prowadzi to do smutnej, acz prawdziwej konstatacji, iż rozwojowi naszej dyscypliny dobrze służy międzynarodowa niestabilność, konflikty i rozlew krwi. Po drugie, polskie analizy strategiczne bardzo wyraźnie skupily się na problemach bezpieczeństwa obszaru euroatlantyckiego. Jest to zrozumiałe i pożądane w obliczu wyzwań stojących przed Polską (oraz całą wspólnotą transatlantycka) oraz doniosłości procesów zachodzących na tym obszarze. Szereg autorów podkreśla jednak, iż liczne kryzysy obejmujące różne regionalne kompleksy bezpieczeństwa (Europa Wschodnia, Bliski Wschód, Azja Wschodnia) są ze sobą coraz ściślej powiązane i wzajemnie się warunkują. W tej sytuacji skromna liczba analiz poświęconych innym regionom świata niż ten, w którym sami się znajdujemy, choć zrozumiała, pozostawia pewien niedosyt.

\section{BIBLIOGRAFIA}

Charap S. (2015), The Ghost of Hybrid War, „Survival”, Vol. 57, No. 6.

Crocker Ch. A. (2015), The Strategic Dilemma of a World Adruft, „Survival”, Vol. 57, No. 1.

Doran Ch. F. (2015), Imperatives of European Security at Russia's Critical point on its Power Cycle, „Stosunki Międzynarodowe”, t. 51, nr 2.

Dybczyński A. (2015), Przyszłość NATO, „Rocznik Strategiczny 2014/15”.

Fryc M. (2014), „Doktryna Komorowskiego” - próba scharakteryzowania. Idea, zakres, priorytety, realizacja, „Bezpieczeństwo Narodowe”, $\mathrm{nr} 2$.

Fryc M. (2015), Polska strategia obronności wobec zagrożenia militarnego z elementami ,wojny hybrydowej”, „Bezpieczeństwo Narodowe”, nr 33. 
Gibbons-Neff T. (2015), The last time a Russian jet was shot down by a NATO jet was in 1952, „The Washington Post", 24.11.2015.

Heisbourg F. (2015), The Strategic Implications of the Syrian Refugee Crisis, „Survival”, Vol. 57. No. 6 .

Holslag J. (2013), The Eurasian Sea, „Survival”, Vol. 55, No. 4.

Kupiecki R. (2015), Obrona kolektywna NATO. Stata misja i zmienny kontekst strategiczny, „Rocznik Strategiczny 2014/15".

Madej A. (2015) Sankcje i kontrsankcje. Przyczyny obecnego kryzysu ekonomicznego w Rosji, „Bezpieczeństwo Narodowe", nr 34.

Madej M. (2015) Spóźniony (i krótkotrwaly) entuzjazm. Polska wobec Wspólnej Polityki Bezpieczenstwa i Obrony w latach 2008-2014, „Stosunki Międzynarodowe”, t. 51, nr 2.

Sliwa Z. (2015), Militaryzacja Arktyki - Federacja Rosyjska zaznacza obecność wojskowa w regionie, „Bellona”, nr 2.

Zajączkowski J. (2015), Strategie morskie Indii, Chin i USA w regionie Oceanu Indyjskiego: analiza w kategoriach realizmu ofensywnego, „Stosunki Międzynarodowe”, t. 51, nr 2.

\title{
STRESZCZENIE
}

Artykuł stanowi przegląd wybranych publikacji zamieszczonych w 2015 r. na łamach czołowych polskich czasopism naukowych o tematyce bezpieczeństwa międzynarodowego („Bellona”, „Bezpieczeństwo Narodowe”, ,Rocznik Strategiczny” oraz „Stosunki Międzynarodowe"). Ma on na celu ukazanie głównych kierunków badań prowadzonych w minionym roku przez polską społeczność studiów strategicznych. Autor przedstawia najważniejsze i najciekawsze stanowiska w głównych debatach toczonych na łamach omawianych publikacji oraz opatruje je własnym komentarzem analitycznym.

Słowa kluczowe: analizy strategiczne, zagrożenia bezpieczeństwa

\section{POLISH STRATEGIC ANALYSIS - REVIEW OF 2015}

\begin{abstract}
The article constitutes a review of selected articles published in 2015 by leading Polish scientific journals dealing with international security („Bellona”, „Bezpieczeństwo Narodowe” [,National Security”], „Rocznik Strategiczny” [,Strategic Yearbook”] and „Stosunki Międzynarodowe" [,International Relations"]). It aims to highlight main directions of research conducted in the previous year by the Polish strategic studies community. The author presents the most important and interesting arguments in main debates undertaken on the pages of reviewed publications adding his own analytical commentary.
\end{abstract}

Key words: strategic analysis, security threats 